\title{
Iraqi Politics and Implications for Oil and Energy
}

\section{Citation}

O'Sullivan, Meghan. 2011. Iraqi Politics and Implications for Oil and Energy. HKS Faculty Research Working Paper Series RWP11-031, John F. Kennedy School of Government, Harvard University.

\section{Published Version}

http://web.hks.harvard.edu/publications/workingpapers/citation.aspx?Publd=7925

\section{Permanent link}

http://nrs.harvard.edu/urn-3:HUL.InstRepos:5116451

\section{Terms of Use}

This article was downloaded from Harvard University's DASH repository, and is made available under the terms and conditions applicable to Other Posted Material, as set forth at http:// nrs.harvard.edu/urn-3:HUL.InstRepos:dash.current.terms-of-use\#LAA

\section{Share Your Story}

The Harvard community has made this article openly available.

Please share how this access benefits you. Submit a story.

Accessibility 


\section{I raqi Politics and I mplications for Oil and Energy Faculty Research Working Paper Series}

\section{Meghan O'Sullivan}

Harvard Kennedy School

\section{August 2011 RWP11-031}

The views expressed in the HKS Faculty Research Working Paper Series are those of the author(s) and do not necessarily reflect those of the John F. Kennedy School of Government or of Harvard University. Faculty Research Working Papers have not undergone formal review and approval. Such papers are included in this series to elicit feedback and to encourage debate on important public policy challenges. Copyright belongs to the author(s). Papers may be downloaded for personal use only. 
GEOPOLITICS OF ENERGY PROJECT

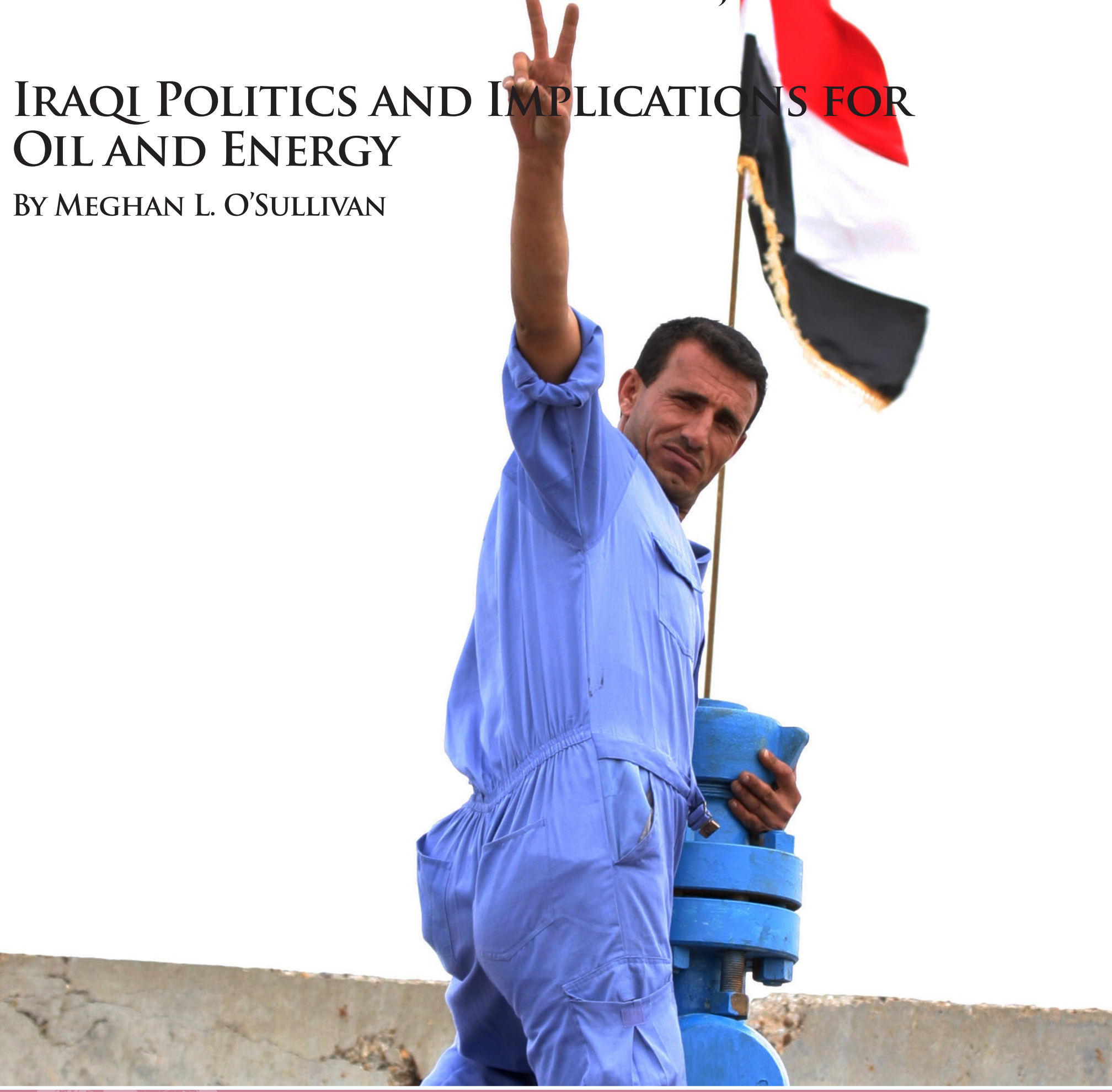

HAR Hennedy School

BELFER CENTER for Science and International Affairs

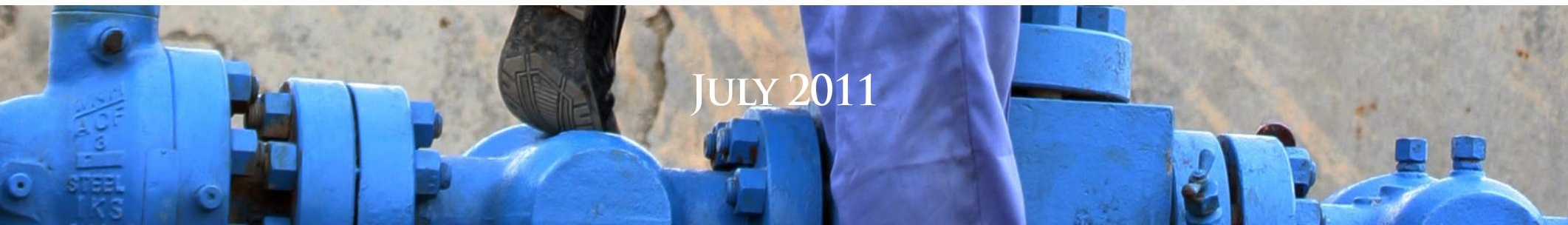


This report was written under the auspices of the Geopolitics of Energy Project at Harvard Kennedy School's Belfer Center for Science and International Affairs and as a specific contribution to a project at the James A. Baker III Institute for Public Policy at Rice University. That project, titled "The Future of Iraq: Implications for World Oil Markets," examines how Iraq's oil and natural gas policies and other developments will affect global markets. The author is grateful for the support of BP, the Dubai Initiative, the Baker Institute, and the Institute for Energy Economics in Japan.

\section{Belfer Center for Science and International Affairs}

Harvard Kennedy School

79 JFK Street

Cambridge, MA 02138

Fax: (617) 495-8963

Email: belfer_center@harvard.edu

Website: http://belfercenter.org

Copyright 2011 President and Fellows of Harvard College 


\section{Introduction: High Stakes for Iraqi Energy}

Iraq's ability to reach its energy potential should be of broad regional and international concern. Iraq could be poised for a dramatic transformation, one in which it finally escapes the political and technical constraints that have kept it producing less than 4 percent of the world's oil, despite having the third-largest conventional oil reserves in the world. Should Iraq meet its ambitions to bring nearly 10 million more barrels of oil on line by 2017, it would constitute the largest ever capacity increase in the history of the oil industry. Should Iraq, more probably, bring only half this capacity to market, it would still represent a massive achievement. ${ }^{1}$

Translating Iraq's energy promise into reality is in the shared interest of Iraq, the United States, Japan, and the international community more broadly. At the highest level, the health of Iraq's energy sector-currently the source of more than 90 percent of revenues accrued by the state-is a major determinant in setting Iraq's overall trajectory. A booming energy economy is not a guarantee of a prosperous, democratic, and stable Iraq; it could also be the hallmark of an Iraq that has returned to authoritarianism or even tyranny. But it is difficult to imagine a prosperous, democratic, and stable Iraq that does not claim a thriving energy industry among its assets.

More specifically, from an Iraqi perspective, developing and monetizing Iraq's underground wealth is the cornerstone of a successful development strategy. After more than 30 years of internal conflict, international war, sanctions, and dictatorship, Iraq's development needs are enormous. Reclaiming Iraq's position as one of the more advanced economies and societies of the region will require huge investments in infrastructure, health, and education. The government's ability to successfully make these investments is the key to the consolidation of the new political system Iraq has created since the fall of Saddam Hussein. A failure to deliver across social and economic dimensions will-and has begun to-put Iraq's fragile democracy under enormous strain. In addition, Iraqis are cognizant that their energy strategy is also their foreign policy strategy and their security strategy. Not only are high revenues needed to build and maintain a military capable of meeting Iraq's internal and external threats, but Baghdad's capacity to re-establish itself as a regional power will be in part a measure of its ability to maintain influence with and over its neighbors on account of their energy links to Iraq.

The United States, Japan, and the international community share most of these interests with Iraq, if bringing a slightly different perspective to the situation. This group is invested in Iraqi stability and the consolidation of Iraq's nascent democracy not only for the benefits it brings to the Iraqi people, but also because it is the foundation of Iraq's relationships in the international arena. Iraq's internal institutions will in large part determine Iraq's external orientation. Particularly now that staunch American allies in the Middle East-such as Hosni Mubarak's

\footnotetext{
${ }^{1}$ See Bernstein Research, The Herculean Challenge of Lifting Iraq's Oil Production, August 3, 2010, p. 2.
} 
Egypt and Ben Ali's Tunisia-are gone, the United States should value governments likely to be sympathetic to its needs and interests in the region more broadly. Although today's Iraq is neither inclined nor able to carry American water in the region at this time, it is certainly more likely to be in broad alignment with the United States in the future than any resurgent authoritarian regime in Baghdad would be.

Similarly, Iraq's stability has major implications for regional stability. Literally sitting on the seams of the Middle East, Iraq embraces nearly every fault line of the region. Its ethnic, sectarian, linguistic, and religious diversity - in combination with its natural resources, robust population, and sheer size-has led every regional power to see its interests as caught up in Iraq's destiny and has justified a wide variety of external interventions by Iraq's neighbors. A fractious Iraq, with uncertain politics and fragile institutions, will instigate more instability throughout the region. While this connection between Iraq and the region is well understood, what may be less appreciated is Iraq's ability to stabilize the region. As revolutions unseat longstanding dictators, few have had time to consider what economic model will alleviate the economic deprivation and frustration that drove many of the recent protests. Unlikely to compete with China's ability to serve as the factory of the world, Middle Eastern nations will need to seek greater economic gains through regional integration. Iraq, given its geographic location, its historical role as a regional leader, and its energy wealth, could be a prime driver of such integration-if it can realize the potential of its oil and gas deposits.

Finally, the international community-particularly large energy consuming countries like the United States, China and Japan-has a major interest in Iraq reaching its energy potential because of the implications of Iraq's success or failure in this realm for energy security. The global recession and accompanying decrease in demand for energy in 2009 and much of 2010 removed concerns over limited spare oil capacity from the forefront of many minds. The new turbulence in the Middle East and the resumption of global energy demand at the end of 2010, however, should remind us that the current spare capacity in the global system is finite. Decisions to further expand capacity have largely been put on hold as producing countries seek to gauge the trajectory of international demand; talk of a "demand peak" due to concerns over climate and the environment as well as economic uncertainties have made countries such as Saudi Arabia reluctant to build more spare capacity.

As a result, the international community is very likely to be reliant on Iraq (and Saudi Arabia) to bring more oil to international markets in the coming years if the world is to avert another supply crunch like that which occurred in 2008. The severity and timing of such a crisis is dependent on a wide variety of factors, such as the growth of Chinese demand and whether Iran remains subject to international sanctions over the long term. But the projections of many companies and international agencies include Iraq bringing substantial quantities of oil to international markets in the coming years. The International Energy Agency envisions Iraq 
bringing on line an additional 3.6 million barrels a day (b/d) of oil to what it currently produces; BP similarly sees Iraq producing 5.5 million b/d in total by $2030 .^{2}$ The inability of Iraq to bring these significant quantities of oil on line in the coming years diminishes the prospect of the world meeting global energy demand at a reasonable price and increases the possibility of another global economic crisis.

\section{Factors Complicating Iraq's Energy Ascendance}

Given the high stakes surrounding Iraq's ability to realize its energy potential, it is no surprise that obstacles to the development of Iraq's energy sector have received substantial attention. The broad conversation surrounding risks to Iraq's energy plans, however, have largely focused on operational and logistical factors. In particular, industry experts and planners lament the huge bottlenecks associated with Iraq's decrepit infrastructure. The dire state of Iraq's energy infrastructure-and corresponding need for international investment-was even the focus of a recent speech by Ambassador Richard Morningstar, Secretary of State Hillary Clinton's special envoy for Eurasian energy. ${ }^{3}$ Iraq's deficit in human capacity, particularly professionals who are able to manage projects and make decisions within the energy related ministries, is also often decried. The limited number of high-level technocrats, combined with the fear of being prosecuted for corruption, has created serious frustrations among international oil companies (IOCs) needing quick decisions. Finally, legitimate concerns persist about the security environment in which much of the development of Iraq's energy resources will take place. Although the country has made huge strides in improving security since the dark days of 20062007, the security environment in many parts of the country remains difficult. While Iraqi and international companies have been able to do business, recent attacks on infrastructure in particular demonstrate the continued difficulty of developing Iraq's energy sector. ${ }^{4}$

While these operational and logistical factors will play a large role in whether Iraq reaches its energy potential, political factors will be equally important. These political matters have received less systematic attention than other factors, perhaps because they are harder to visualize, understand, or resolve through the commitment of more financial resources or sheer hard work. Nevertheless, the resolution or management of several political issues is essential to the smooth development of Iraq's energy. The remainder of this paper considers five such factors, explaining the nature of the current political challenge, its implications for energy, and its prospects for resolution.

\footnotetext{
${ }^{2}$ See International Energy Agency, World Energy Outlook, 2010 and BP, BP Energy Outlook, January 2011.

${ }^{3}$ Ambassador Richard Morningstar, Remarks delivered at CERA Week 2011, Houston, Texas, 7 March 2011.

${ }^{4}$ There has been a notable uptick in attacks on energy-related installations in the first half of 2011. Some believe that Al Qaeda has an explicit strategy of attacking energy infrastructure as a way of destabilizing Iraq. Insurgents waged a critical attack on the Beiji oil refinery in February 2011 and again in June 2011; subsequent attacks have focused on smaller installations, but all with the intention of creating major disruptions to the flow of resources and the ability of the Iraqi government to collect revenue.
} 


\section{Political Stability}

The single most important political factor for Iraq's energy development is political stability, not just of the current government of Prime Minister Nouri al-Maliki, but of the current postSaddam system. Like other countries in the Middle East, Iraq has experienced a number of public protests in 2011. But unlike in Egypt, Tunisia, or Libya, such protests have not sought to change the nature of the regime, or even remove the current individuals from power. Instead, these protests have focused on the socioeconomic conditions that many Iraqis endure and have provided a vehicle for expressing desires for greater freedom and accountability of the government. It is no small matter that most Iraqis are now committed to a democratic system; unlike in years past, calls rejecting Iraq's new institutions are no longer often heard. But nearly eight years after the removal of Saddam, Iraqis are still facing high levels of unemployment and minimal provision of social services from the state. The most common concern is the lack of electricity. Demand for electricity has more than doubled since 2003 while supply increases have been more modest, leading to a persistent gap between supply and demand. Protests over the paucity of power fueled angry protests in Basra and Nasiriya as early as a year ago and led to the resignation of the Minister of Electricity in summer 2010.

The Maliki government, watching events in the region closely, has thus far reacted to the protests of 2011 through a number of initiatives. The prime minister has suggested he will not seek to become prime minister again after his current term concludes. He has also returned half of his salary to the national budget. The government has taken steps aimed specifically at easing shortterm hardships, including pledging to provide free fuel to both private and government generators with the understanding that the operators will supply electricity to the grid at reduced prices. ${ }^{5}$ The deputy prime minister for energy, former oil minister Hussain Shahristani, declared free electricity for Iraq's poorest and the government as a whole has shifted some of its spending priorities within the current budget to try to meet popular demands more quickly. ${ }^{6}$ In June 2011, the Iraqi cabinet approved $\$ 927$ million in supplementary funds for "strategic projects" for electricity generation. ${ }^{7}$ Despite these efforts to be responsive to the street, public protests led to the resignation of two of Iraq's provincial governors during the first half of 2011.

The result of this wave-albeit small by regional standards-of public pressure on Iraq's government is not yet clear. It is possible that pressure from the populace could spur the members of the Maliki government to pull together to focus on delivery of services to Iraqis in a way that previous security conditions and political rivalries made nearly impossible. The need to respond to an increasingly restive and vocal population helps explain several recent

\footnotetext{
${ }^{5}$ Ben Van Heuvelen, “Heading Off Summer Power Protests,” Iraq Oil Report, May 27, 2011.

${ }^{6}$ Iraq has reportedly suspended the purchase of fighter jets in order to allocate more resources to the food basket distributed to Iraqi citizens.

${ }^{7}$ Middle East Economic Survey, “Iraq Approves \$927mn Additional Budget for Power Projects,” June 19. 2011.
} 
developments: the decision to sign an agreement for a pipeline to bring gas to Baghdad from Iran, the creation of a "master plan" for electricity, and the apparent resolution of the three-year old stalemate between the Iraqi government and Shell over the development of Basra gas. ${ }^{8}$ A pulling together effect would be beneficial for the industry, as it would add impetus to nascent efforts to look at Iraq's energy sector as a whole and develop a strategic, integrated plan for it.

In reality, popular pressure on the Maliki government is more likely to be deleterious to energy developments than it is to be beneficial. Such pressures could lead the prime minister to further consolidate power, which could further galvanize popular and-importantly-political elite opposition to the prime minister. ${ }^{9}$ The implications for energy sector development could be farreaching. Increased political strain within the government will reinforce existing tendencies toward short-term thinking. ${ }^{10}$ Iraq should be deciding its stance on strategic questions-such as whether its goal is to maximize revenues or production or whether it wishes to develop and hold spare capacity - and formulating its plans in light of its answers. Instead, the energy sector of the country is still driven more by a sense of political urgency and has not yet internalized the idea of opportunity costs. The result is that Iraq is falling short of the achievements it is capable of realizing and it may be setting itself up for failure or crisis further down the road. For instance, if Iraq-in its focus on boosting oil production-brings so much oil to market that there is a price collapse, the country could end up with fewer revenues than it earns today, despite producing more oil.

More extreme political scenarios are possible, but much less likely. Political opposition to Maliki-on the streets and within his own government-could conceivably lead to his ouster as prime minister. Although the removal of a prime minister can be achieved by a simple majority vote in Parliament, the more difficult process of forming a new government has been an effective

\footnotetext{
${ }^{8}$ On July 13, 2011, the Iraqi government and Shell initialed a gas deal that had been languishing since 2008. The deal, which gives Shell and its joint venture partners the right to handle all associated gas from the large Basra fields, ran into repeated delays for multiple political, legal, and technical reasons. The first, and most prominent, is the sole-source nature of the deal. Unlike the contracts awarded through the bid rounds, the Shell deal happened through bilateral channels with little transparency. Second, the deal was under intense scrutiny because its focus appeared to be on exporting Iraqi gas, at a time when Iraq is dramatically short of electricity and, many argue, should be focused on provision of services to Iraqis. A Shell official, in commenting on the July breakthrough, suggested an arrangement in which domestic needs would be met before export. Another reason for the delays was that the landscape changed significantly in Basra since the Shell agreement was envisioned; IOCs now are responsible for increasing production in these fields and may well wish to use the associated gas for their own uses. Finally, a raft of legal issues dogged the contract, including a law demanding that all exports flow through the State Oil Marketing Organization (SOMO).

${ }^{9}$ As of mid-July 2011, Prime Minister Maliki had still not appointed ministers to the security portfolios, but was maintaining these files himself. The government has reacted to protests with force in some cases and has exerted political pressure on parties supporting those protesting. Most recently, the prime minister has sought to gain control over formerly independent commissions. See New York Times, “Mr. Maliki’s Power Grab,” March 13, 2011, for commentary.

${ }^{10}$ For instance, Iraq will move away from efforts to charge for electricity and will divert limited electricity supply from productive sectors to residential ones.
} 
break on this action in the past. Theoretically, Iraq's protests could result in a breakdown of the system and collapse of the country's institutions and subsequent lapse into civil disorder; this scenario is very much at the margins. In terms of the implications of these more extreme scenarios, the removal of the current prime minister would undoubtedly slow down decisionmaking, suspend any future bid rounds, and open a wider door to opposition to the existing contracts. It would not, however, likely signal the end of Iraq's efforts to ramp up production and export of oil and gas. The most extreme and very unlikely scenario of civil chaos, in contrast, could be consistent with a suspension of current operations and a return to energy stagnation depending on the scope and depth of unrest.

\section{Power Sharing Arrangements in Baghdad}

Even if we assume that the wave of popular mobilization sweeping the Arab world, and touching Iraq, has no appreciable effect on political stability, the nature of the current government in Iraq is an important factor in understanding the prospects for Iraq's rapid energy development. After nine months of painful political stalemate following the March 2010 parliamentary elections, Iraq formed a government at the end of last year. The stalemate-and to a great extent the face and form of the government-was the product of a very close election. Former prime minister Ayad Allawi's Iraqiya coalition, an alliance of cross-sectarian nationalists and Sunni-based parties, won the most seats in Parliament. The party of the incumbent prime minister, Nouri al-Maliki, was a close runner-up with only two seats less. Jockeying over the meaning of certain constitutional provisions concerning government formation and incessant politicking between possible coalition partners finally ended with the formation of a government of national unity. All parties winning any sizable number of seats were awarded ministerial or other prominent posts according to an elaborate formula and pre-government formation deals. Ayad Allawi, although ceding to Maliki in the competition to be prime minister, was promised an influential position as the head of a new executive body with a broad mandate over strategic issues.

As has happened on each occasion in Iraq's post-Saddam era, the need for inclusion won out over the need for effectiveness. Had Maliki formed a government without the cooperation of Iraqiya, the overall stability of the government would have been at risk. Iraqiya felt that it had "won" the election; to exclude it from government would have alienated the Sunnis who supported the coalition in large numbers, possibly reversing years of effort to bring Sunnis into the political process. The result, however justified, is a cabinet that has internalized all of Iraq's political differences. The cabinet has more than 40 members, many of whom are themselves heads of political parties. ${ }^{11}$ In Iraq's highly party-centric polity, these ministers may feel empowered to resist Prime Minister Maliki's directions and pursue contrary agendas. There are also three deputy prime ministers, including one for energy matters. The creation of this

\footnotetext{
${ }^{11}$ Prime Minister Maliki has recently called for downsizing his cabinet, although doing so will be difficult given existing political arrangements.
} 
position, and its assumption by former oil minister Hussain Shahristani, may create confusion as to who is in charge of decision-making related to oil.

Perhaps the most problematic power-sharing arrangement, from the perspective of the smooth functioning of the energy sector, would be the creation of the National Council for Strategic Policies (NCSP). This entity was envisioned and promised as a means of creating an influential and sufficiently attractive post for Ayad Allawi so he would relinquish claims to the premier post in the wake of the close election. The NCSP was conceived to be an extra-constitutional body that is comprised of the leaders of every political party in Parliament. Parliament is to pass legislation mapping out the mandate of the body and the mechanisms by which it functions. Political agreements sealed before government formation anticipated authority over a broad range of policy matters, including the energy sector. Although the threshold for binding decisions is expected to be high at 80 percent, this body was conceived to have true executive authority.

The potentially complicated implications of the not-yet-formed NCSP for energy development are evident. The 80 percent threshold would make it unlikely that the programs of the prime minister would be overturned by the NSCP, but that is not an impossible outcome. Exactly what the role of the NCSP would be in the signing and execution of oil contracts is unclear, but the body would almost surely want to give contracts its imprimatur. The NCSP would certainly expect to have the ability to shape and approve any broad strategy for the sector, which could result in mixed signals, poor decision-making, and paralysis.

Partially due to the difficulties of what is effectively splitting executive authority between the cabinet and an extra-judicial body, efforts to translate political agreements about the NSCP into political reality have stalled. In March 2011, Ayad Allawi publicly announced that he would no longer head the body even if it were to be established; subsequent negotiations continued in the hope that he could be convinced otherwise. ${ }^{12}$ Given these developments, the NSCP may never be established or, if it is, it could be a much-emasculated version of the original concept. The ignominious failure to establish this body-which was such a key component of the final deal to form the government-bodes badly for the current government's ability to maintain broad political support. ${ }^{13}$ It, however, would likely keep Iraq's energy plans from suffering from yet another layer of complexity.

\footnotetext{
${ }^{12}$ See New York Times, “Iraqi Coalition Leader Balks at Post, Dealing Government a Blow,” March 3, 2011.

${ }^{13}$ The impact of the collapse of this component of the agreement, however, will be less than originally anticipated. Although Allawi's alienation from the government is a serious loss, it will not precipitate a withdrawal of Iraqiyah from the government as whole. Too many members of Iraqiyah have already established themselves in high places and the coalition has begun to fracture and lose force as a political entity.
} 


\section{Resource Nationalism and Contract Sanctity}

The decision to invite IOCs into Iraq to help the country develop its energy resources was a difficult and hotly contested one. The government of Iraq nationalized its oil industry in 1972 and, despite the negotiation of production-sharing agreements in the 1990s pending the lifting of United Nations (U.N.) sanctions, no IOCs had done business in Iraq since that time. In the wake of the American-led occupation, Iraqis debated whether they really needed international help to increase the levels of oil production, or whether they had sufficient capacity, technology, and resources to do it on their own. Failure to agree to a new oil law governing investment in Iraq's energy sector added to the stasis and it was not until 2009 that Iraq offered its first bid round for the development of some of its largest producing fields.

Given the inability to agree on new legislation (see next section), the three bid rounds that were conducted in 2009 and 2010 were done under an Iraqi law dating back to $1967 .{ }^{14}$ This law, while not precluding production-sharing agreements, is read by many as requiring Iraq's parliamentary body to approve of all upstream contracts. This requirement was of little consequence when Iraq's Parliament was a rubber stamp body for Saddam's decisions. In the post-Saddam Iraq, however, Parliament has real authority and much greater autonomy from the executive, making the prospect of a parliamentary rejection of such sensitive contracts real. While some anticipated that IOCs would be reluctant to invest billions of dollars with such uncertainty around the oil law, the results of the bid rounds suggested otherwise.

The earlier government, also led by Prime Minister Maliki, handled the issue of contract approval deftly, arguing that approval by the cabinet was sufficient for the finalization of the contracts. This approach, in conjunction with the excellent terms perceived to have been negotiated by Iraq, the technical service nature of the contracts, and the transparency of the bid rounds, largely quelled any real opposition of Parliament; the bid rounds, and the execution of the contracts that resulted, continued apace. The one sustained challenge to the legitimacy of these contracts, championed by former parliamentarian Shetha Musawi, died in court on a technicality.

The pressing question for today is whether the relatively new Parliament-or any members of the new government-will challenge the legitimacy of the contracts or their specific terms. In considering this issue, one should note that the overwhelming majority of Iraq's members of Parliament today are new to office; the anti-incumbency vote swept away most of the sitting parliamentarians in the March 2010 election. In addition, one should note the statements made by politicians and parties in the run-up to the election. Iraqiya, the party of Ayad Allawi, made known its view that all existing contracts-within Iraq as a whole and those signed by the

\footnotetext{
${ }^{14}$ Iraq's constitution says that existing laws maintain their legality unless specifically revoked or superseded by new legislation.
} 
Kurdistan Regional Government (KRG) - required review by Parliament and possible renegotiation. ${ }^{15}$ Moqtada al-Sadr, the radical anti-American leader of the Sadrist movement, took an even stronger stance, arguing against involvement of IOCs in Iraq's oil industry on the grounds of nationalism. ${ }^{16}$

The formation of a national unity government, however, has diminished the chances of a frontal assault by political parties on the existing oil contracts for a number of reasons. Most importantly, the coalitions and parties most vocally critical of the contracts-Iraqiya and the Sadrists-are now part of the sitting government. Even if Ayad Allawi distances himself from the government as discussed above, it would be difficult for him to bring his coalition out of government as an entire bloc, as many from Iraqiyah are already in positions of power and influence and would be reluctant to relinquish these roles. ${ }^{17}$ The prospect of a robust, Iraqiyahcentric opposition that might take up the issue of the legitimacy of oil contracts is therefore minimal. The Sadrists are also now inside the political tent, holding the positions of deputy speaker of Parliament as well as several ministries; they are now also invested in the success of the government. In short, one virtue of the broadly inclusive government described above is that few players have any incentive to take steps that would inevitably result in depriving the government of much-needed resources about to come on line. Iraq's recently concluded 2011 budget plans for $\$ 83$ billion of expenditures; meeting the needs envisioned in the budget will require robust oil exports.

While the political parties may be less likely to champion wholesale revisions of the existing contracts, Parliament is exerting its prerogatives and seeking to challenge the government's ability to continue to develop the oil sector without its involvement. Adnan al-Janabi, the chairman of the Oil and Gas Committee of Iraq's Parliament, has clearly expressed his view that all contracts-in the Kurdistan Regional Government as well as the south-need to be reviewed because they were completed in the absence of binding legislation governing the development of the energy sector. In July 2011, the committee submitted a motion to Parliament seeking a vote that would call for a moratorium on the signing of any new oil or gas contracts until new hydrocarbons legislation is passed. The initiative is more intended to add urgency to the ongoing effort to resolve national differences about such legislation than it is an effort to stop foreign companies from entering Iraq. The committee has breathed new life into other, related

\footnotetext{
${ }^{15}$ See Iraqiya statement in October 2010 on the gas bid round which claimed, "These actions are also considered illegal in light of the current constitutional and political vacuum engulfing the country." Reuters, "Iraq's Sunnibacked Political Bloc Rejects Gas Auction,” October 24, 2010. Maysoon al-Damluji, an Iraqiya member and key adviser to Iraqiya leader Ayad Allawi, claims all contracts need to be reviewed in Ben Lando, "Iraqiya Against Gas and Oil Deals,” Iraq Oil Report (online at www.iraqoilreport.com), October 26, 2010.

${ }^{16}$ In response to a query from a follower, Moqtada al-Sadr recently forbade his followers from working for an unnamed British drilling company. No stance was taken on non-British companies. See Ben Van Heuvelen, "Luaibi to head Oil Ministry, Shahristani to DPM,” Iraq Oil Report (online at www.iraqoilreport.com), December 21, 2010.

${ }^{17}$ For instance, the speaker of parliament, Osama Najafi, is from Iraqiyah, as is one deputy prime minister and the ministers of finance, agriculture, education, communications, and science and technology.
} 
debates as well. Most notably, the committee held July 2011 hearings on whether Iraq should reestablish an Iraqi National Oil Committee. ${ }^{18}$ While those who testified presented a range of conflicting views, the hearing added momentum to recent efforts to resolve long-standing roadblocks in Iraq's energy sector (see below). ${ }^{19}$

Even without a Parliament-induced examination of the existing contracts, some will be revised in the months and years ahead. Questions around the structure of the contracts are becoming more frequent, even among those in government, as the Iraqis realize that the contracts provide huge incentives to companies to ramp up production quickly to begin cost recovery, perhaps to the long-term detriment to the fields. ${ }^{20}$ Other impetuses to marginal renegotiations down the line could be the need to handle shut-in production due to Iraq's adherence to an OPEC quota, or the mutual desire on the part of the government and the IOCs to shift responsibility for infrastructure development.

\section{Federalism and Constitutional Issues}

The most fundamental disagreement in Iraq today relates to the nature of the state: should Iraq be a federal country or a more centralized one as it has been throughout history? Iraq's constitution explicitly declares Iraq a federal state, recognizes the status of the Kurdistan Regional Government and its authority over a broad range of matters, delineates the rights of current provinces to become "regions" with their corresponding powers, and even declares regional laws as superior to federal ones. Despite these strong statements in support of Iraq as a federal state, the matter has continued to be debated, with many Arab leaders declaring their opposition to federalism beyond the Iraqi Kurdistan. Like many traditional Arab states, the commitment to a strong central government runs deep among many Iraqis, some of which see federalism as a precursor to the breakup of the state. In contrast, Kurdish leaders see their ability to maintain a semi-autonomous region as a precondition to their union with Iraq; few issues carry more emotional weight in Kurdistan. This debate, however, is dynamic and has taken some interesting turns in the recent year, particularly as parts of Iraq become increasingly frustrated with the ability of Baghdad to provide basic services.

The Iraqi ambivalence toward federalism is reflected in the country's constitution. In many places, the constitution stipulates that certain matters-such as the exact shape of a second chamber of Parliament allegedly to represent regional interests-will be clarified in legislation to

\footnotetext{
${ }^{18}$ The Iraq National Oil Company was established in 1967, but then disbanded by Saddam in 1987.

${ }^{19}$ For details on the hearing, see Ben Lando, “Oil Experts Debate a New State Oil Company,” Iraq Oil Report, July

7, 2011.

${ }^{20}$ Interview with Thamer al-Ghadban, currently chairman of the advisory commission in the office of Iraqi Prime Minister Maliki and Maliki's top energy adviser. He was formerly Iraq's oil minister. For explanation of cost recovery mechanisms and the incentives created, see Deutsche Bank, Iraq: The Mother of All Oil Stories, Global Markets Research, October 4, 2010, pp. 16-18 and Muhammed Mazeel al-Aboudi, "Iraq's TSC and PSC Agreements - A Good Deal for Iraq?” Middle East Economic Survey LII, no. 3 (January 18, 2010).
} 
be passed by the Parliament. In other places, particularly those relating to oil and gas, the constitution is intentionally ambiguous; the ability of both Kurds and Arabs to read what they wanted to into certain provisions was key to the passage of the constitution when it needed to hurdle a referendum in 2005.

These complex issues related to federalism and the constitution have had profound effects on the development of Iraq's oil and gas industry to date. Their resolution-or festering-will undoubtedly have major implications for the future of Iraqi energy. Two broad sets of related issues warrant further examination: tensions between Baghdad and the KRG over the development of energy and growing impulses toward provincial empowerment or federalism in Arab provinces.

Tensions between Baghdad and the Kurdish Regional Government

Since the completion of the constitution, leaders from the federal government in Baghdad and the KRG have sought to resolve their differences over how energy should be developed in the country. The disagreements-although multiple and varied-stem from this fundamental divergence of opinion over whether power should reside primarily in Baghdad, or in the regions. Two issues in particular have festered related to oil and gas. First, Baghdad and the KRG disagree over which entity has the right to develop the resources in the region (i.e., the KRG). The constitution includes vague language on this matter, suggesting that Baghdad will have primary authority over "existing" fields. "New fields," the Kurds claim, therefore fall into the purview of the regions and can be developed according to Kurdish decisions without input or approval from Baghdad. Second, Baghdad and the Kurds have differed over what are appropriate contracting mechanisms for the development of Iraq's resources. Baghdad has stuck to technical service agreements, while the KRG has awarded lucrative production-sharing agreements to IOCs. Other related matters are additional irritants in the relationship, including exactly how the budget is handled and national oil revenues are divided.

Attempts at reconciling these views or creating acceptable compromises essentially ground to a halt in 2007; the cabinet approved draft oil and gas legislation, but the Parliament failed to do the same. In the absence of an agreement, the KRG passed its own oil and gas legislation and proceeded to award dozens of production-sharing agreements to IOCs for exploration within its boundaries. Baghdad declared such contracts to be "unconstitutional" and therefore illegal. Until today, Baghdad blacklists any IOC involved in the KRG from competing for contracts in the rest of the country.

The implications of this impasse for the oil and gas industry have been significant. Until recently (see below), the KRG has been virtually unable to export production that has come on line since the contracts were awarded; Baghdad has for the most part denied the KRG the ability to use federal infrastructure for export. The blacklisting of companies operating in Iraqi Kurdistan 
forced the KRG to turn to very small companies, some of which probably do not have adequate technology to do the work required. Finally, the impasse over the oil and gas laws has, as mentioned above, created uncertainty in the minds of international investors, who are already assuming significant risk by investing in Iraq.

After many years of no progress on these issues, several factors have pushed them to the fore once again. First, as a precondition to supporting Maliki to be the prime minister in the current government, the Kurds reportedly extracted promises that disagreements over oil and gas issues would be resolved in 2011. Second, and perhaps more compelling, is that the interests of Baghdad and the KRG are now aligned. Baghdad needs to export more oil to fund its $\$ 83$ billion 2011 budget, but infrastructure difficulties cap significant export increases from the south in the short run. ${ }^{21}$ The KRG, which had curtailed production due to lack of export options, is eager to ramp up, demonstrate its ability to export, and bring in funds to pay IOCs that have been working in the region.

These two impetuses have in fact led to some notable progress in recent months. For the first time since 2007, Iraqi politicians have resumed in earnest efforts to resolve the legislative impasse. As noted above, the new parliamentary chairman is using the mechanisms open to him to infuse urgency into the system; the cabinet has also reexamined legislative drafts and intends to submit them to Parliament. More tangibly, a deal struck between Prime Minister Maliki and Barham Salih, the prime minister of Kurdistan, opened the door for the export of Kurdish oil through federal infrastructure beginning in spring 2011. Companies in Kurdistan have resumed production, reaching more than $180,000 \mathrm{~b} / \mathrm{d}$ by mid-2011. Even more significant than the export of Kurdish oil was the May 2011 payment made by the federal government to the KRG to repay the costs of companies paying Kurdish oil. Although questions remain over who will pay the "profit oil" the international companies are entitled to according to the contracts they signed with the KRG, the payment of costs was a breakthrough event.

While this positive momentum is encouraging, the tougher issue to resolve will be the reconciliation of contracts between Baghdad and the KRG. Recent statements by Prime Minister Maliki and Oil Minister Luaibi already suggest a possible rationale for reconciliation: the more generous production-sharing agreements were warranted in Iraqi Kurdistan because the geology was more challenging and the contracts were for exploration, not brownfields. Nevertheless, one should not underestimate the high stakes surrounding the resolution of this issue. It has not only become an issue of personal pride for some in the government, but it will inevitably set an important precedent for the future development of Iraqi fields, possibly even by new regions and existing provinces.

${ }^{21}$ The 2011 Iraqi budget explicitly stipulated that 100,000 b/d of exports should originate from the KRG. 
Growing Interest in Provincial Empowerment and Federalism

Provincial activism is perhaps the greatest unappreciated challenge to efforts to construct and consolidate post-Saddam Iraq today. The execution of actual and perceived powers by provincial governments outside the framework of a widely accepted arrangement with Baghdad about the sharing of revenues could undermine the basis of the state. While such concerns have existed in theory for years, developments within the last nine months have made them real and urgent.

Much of the current dilemma stems from the ambiguous attitude toward federalism at the time of the drafting of the constitution. The Kurds insisted on a federal state as somewhat of a precondition for their participation in the new Iraq. As mentioned above, few others in Iraq were eager to embrace federalism more broadly at the time. The drafters of Iraq's constitution, rather than creating a system of asymmetric federalism, included provisions in the document that would allow Iraq's other (non-KRG) provinces to assume more powers and even the status of a federal region over time.

Since 2003, both the Iraqi central government and the United States have invested in the development of provincial governments. Provincial councils were established for the first time during the 2003-2004 occupation; elections to these entities occurred alongside national ones in 2005. A prominent focus of U.S. assistance has been to build up the capacity of these provincial governments in order to make them better able to respond to the demands of those who elected them. More recently, the central Iraqi government granted provincial governments one dollar of revenue for every barrel of oil produced in their territories.

The growing capacity of these provincial entities-combined with disillusionment over the ability of Baghdad to meet local needs-is leading many provincial authorities to extend the limits of their authorities. An added impetus is the example of the Kurdistan Regional Government; many provincial authorities have visited the KRG and been struck by the comparatively advanced levels of development, investment, and infrastructure there. Most return asking whether a more vigorous exertion of provincial powers-even along the lines exercised by the KRG-could bring greater benefits to their own areas.

This provincial empowerment is most problematic in the realm of oil and gas, in large part because of many ambiguities in the constitution and law and because of the lack of an agreed framework on the sharing of revenues. What is clear is that the federal government is not the sole actor in the development of Iraq's resources; the constitution explicitly-although somewhat vaguely-mandates consultation between the federal government and the regions and provinces in the setting of energy strategy and development. Many Iraqis read these documents as promising provinces the same authorities exercised by the regions (i.e., the KRG). 
Given these impulses and ambiguities, it is not surprising that provincial authorities have already begun to influence the environment for Iraq's energy development outside of Kurdistan, namely in various provinces in the South and West. The assertion of power and rights by provincial entities has begun to create obstacles to granting contracts to IOCs. Most notable was the difficulty surrounding the contract awarded in the third bid round to Kogas and KaMunaiGaz for the Akkas field in Anbar. The provincial governor and the provincial council resisted the inclusion of Akkas in the third bid round and subsequently created serious obstacles to the contract being signed. The Anbaris' largest objection to the contract had to do with the export of gas originating in Anbar at a time when Anbar desperately needs gas for electricity and industrialization. ${ }^{22}$ Multiple meetings between the IOCs, the Ministry of Oil, and provincial officials were required to resolve the impasse before finalizing the contract in June 2011, almost nine months after its award. Although there is no clarity over whether provincial entities can technically veto a contract, the noncooperation of the provincial government would be a serious obstacle in the contract's execution.

The tussles with the Kogas contract in Anbar appear to be the beginning-not the end-of such disputes. Although no other contracts have been delayed, a new trend is the pursuit of contracts to be signed exclusively between the provincial governments and foreign companies to explore and develop resources within a province. Many provincial entities suspect that Baghdad will remain focused on the large fields, primarily in the South, and their own resources will not receive adequate attention for years to come. Such developments add much greater urgency to efforts to devise and agree upon legislation for the overall development of Iraq's resources. The legislation regarding the sharing of revenues and the creation of structures to formalize the coordination between the central government, the region(s), and the provinces is more critical than ever. Whereas the lack of agreement on these issues has created constant friction between Baghdad and the KRG, the stakes today are even higher. As recent developments outside the KRG make clear, a continued failure to create a widely accepted framework threatens to derail Iraq's ability to craft and execute a national energy strategy. Even more seriously, this failure could, over time, staunch the flow of resources to the central government and therefore its ability to maintain the basic functions of a state, such as a national military.

\section{Regional Dynamics}

Iraq's regional relationships will also have a bearing on the country's ability to fully develop its energy resources. Although significant progress has been made in integrating Iraq back into the

\footnotetext{
${ }^{22}$ To appreciate the perspective of Anbari officials, see the interview with Anbar Governor Qasim Abid in Ben Lando, “Anbar's Power Play,” Iraq Oil Report (online at www.iraqoilreport.com), June 1, 2010. Also see Ben Lando, "Sunni Nationalism Eyes Autonomy," Iraq Oil Report (online at www.iraqoilreport.com), November 8. 2010.
} 
region, Iraq's relationships with many of its neighbors remain tense. ${ }^{23}$ While a variety of historical, cultural, and political factors explain these tensions, economic issues, particularly those related to energy, will increasingly shape Iraq's external affairs.

One need not look far to see how Iraq's ability to manage its regional relationships affects its energy prospects. Perhaps of most immediate consequence is Iraq's ability to gain sufficient export routes for its oil. Iraq is making strides in increasing oil production in accordance with the contracts signed with IOCs in 2009 and 2010, but is running up against limited options for exporting these higher volumes. Although ambitious plans are under way to create more export facilities, Iraq will need all the export routes it can develop if it dramatically increases production as planned and wishes to monetize this production. Reopening now-defunct pipelines through Syria and even Saudi Arabia will create important alternate avenues for export. ${ }^{24}$ Kuwait could create difficulties for Iraqi efforts to expand port facilities in Basra; Kuwait has started construction of a new $\$ 1.1$ billion port on Bubyan Island; it has been seen by Iraq as an intentional effort to compete with and block access to its planned Fao Port. Maintaining good relations with Turkey-and refurbishing the existing pipeline between the two countries-will also be essential to the smooth flow of Iraqi exports.

Iraq's efforts to expand its energy footprint could also run into problems in the region if countries, or other entities, decide to seize Iraqi oil as a means of addressing outstanding debts by the Iraqi government. Since 2003, a combination of an American executive order and U.N. resolutions protected Iraqi assets from attachment; concomitant efforts to obtain debt relief for Iraq were extremely successful. The U.N. protection expired in mid-2011, technically opening Iraq to such challenges. While a number of countries conceivably could seek to take advantage of this lapse, Kuwait is the most likely one to do so. Although the exact number is disputed between Iraq and Kuwait, Baghdad still owes Kuwait tens of billions of dollars in reparations for its 1991 invasion. Iraq, in fact, continues to provide Kuwait with 5 percent of its oil revenues to gradually meet these obligations. In the absence of a broader agreement between Iraq and Kuwait, Kuwait may seek to seize Iraqi oil as payments for the reparations. ${ }^{25}$

Finally, regional actors could seek to slow Iraq's growth in production, perceiving it to be a challenge to their own regional position, global status, and economic health. Iran and Iraq have long been "paired" in OPEC as having comparable reserve bases and production capacities; both held essentially the same quota during the years running up to the 1991 Gulf War. (Iraq has not

\footnotetext{
${ }^{23}$ Most recently, Iraq has been selected to host the next Arab League summit, although that meeting was postponed from May 2011 until a later date in 2012.

${ }^{24}$ While there are currently no talks about reopening the Saudi pipeline, the Syrian and Iraqi governments are in open discussions about reopening the pipeline to Syria.

${ }^{25}$ There are still many outstanding issues to be resolved between Iraq and Kuwait, including land and sea borders, mechanisms for developing oil fields straddling the border, and the extent of reparations still required.
} 
been subject to a quota since that time.) In recent years, Iraq has made clear that it sees Saudi Arabia-not Iran-as its natural peer in the region. The 2009 and 2010 bid rounds and subsequent contracts-which, if fulfilled in full, would have Iraq producing more oil than Saudi Arabia-underscore that point. While Iraq may be confident of its resource base and even its ability to bring significant new oil to global markets, both Iran and Saudi Arabia are likely to be threatened by that prospect. Iran is interested in gaining and maintaining influence over Iraq's energy strategy and in integrating the energy infrastructure of both countries; it does not want to see Iraq as the dominant producer in such a partnership. Saudi Arabia's interests are even more vital, given that its international clout is largely tied to its position as the sole swing producer in OPEC. Were Iraq to decide to develop and maintain spare capacity-a policy issue on which there is currently no consensus in Baghdad-it could seriously undermine Saudi Arabia's ability to play this strategic role. Moreover, particularly in wake of the Arab Spring, both Iran and Saudi Arabia are nervous about any developments that could dramatically force down the price of oil and, therefore, their overall revenues. If Iraq were to bring large quantities of additional oil on line in an uncoordinated fashion, the price of oil could well tumble. It is almost inevitable that such issues will affect regional dynamics in the years ahead. What is as yet undetermined is the regional environment in which they will be tackled. If the relationship between Baghdad and Riyadh in particular is not improved in the interim, the prospect for smooth resolution of these challenges is dim.

\section{Prescriptions and Conclusions}

The ability of Iraq to reach its energy potential and bring significant quantities of oil and gas to international markets in the coming years is truly a strategic issue not only for Iraq, but also for the United States, Japan, and the international community. While many focus on the very real operational and logistical challenges to Iraq's development, political factors will be just as important in determining Iraq's energy future. The stability of the government and the regime, the power sharing mechanisms created to ensure the buy-in of Iraq's communities, the continued hum of resource nationalism, constitutional ambiguities about Iraq's federal nature, and the quality of Iraq's regional relationships will all come into play. These political factors will strongly influence Iraq's ability to develop itself in the broadest sense, to play a constructive role in the region, and help the world meet growing energy demand at reasonable prices.

The agenda for resolving these political issues is daunting. It is both complex and urgent. Many of these political issues-particularly ambiguities and disagreements surrounding the relative powers of the central government, the KRG, and the provinces in developing energy resourceshave festered for a long time. But a continued failure to resolve them holds increasing risks for Iraq as a whole. Every week that goes by in which the political issues discussed are not addressed adds to the opportunity costs incurred by Iraq; the country falls short of meeting its energy 
potential. But every week of nonresolution also increases the chances that Iraq will be unable to resolve the issues in the optimal manner as new realities take root on the ground and in the region.

For the most part, the onus for resolving the political issues discussed lies with Iraqis. There are, however, a variety of ways in which the United States and the international community can buttress Iraq in its efforts to address these challenges. After all, the institutions in Iraq are new and cannot be expected to be able to bear the burden of all nation-building challenges simultaneously. And in order to tackle many of the issues discussed, Iraq will need to grapple with big fundamental and strategic matters - such as the nature of the state and the role that Iraq wants to play in the region.

One could identify a number of specific initiatives that the international community could take, to include active involvement in helping Iraq improve its relationship with its neighbors. While such initiatives are important, the most urgent priority at the moment is setting the U.S.-Iraq bilateral relationship on firm footing. Although the U.S.-Iraq bilateral relationship stretches beyond the workings of the Iraqi state, it is very important to the overall trajectory of Iraq and, therefore, to the development of Iraqi energy.

The current bilateral relationship is shaped by the existence of two jointly negotiated agreements: the 2008 Security Agreement and the 2008 Strategic Framework Agreement. The first provides the legal framework for the presence and conduct of U.S. troops in Iraq. It is due to expire at the end of 2011; in the absence of a renewal or renegotiation, all U.S. troops will need to depart Iraq by the coming December. Small numbers-likely in the hundreds-will be able to stay for very limited, noncombat missions. The Strategic Framework Agreement is much broader and aspirational in nature. It lays out a vision of an ongoing bilateral relationship between Iraq and the United States grounded in shared, nonmilitary realms. The agreement speaks of exchange and assistance to Iraq in scientific, cultural, diplomatic, educational, and other areas.

The future of this relationship is not certain at this time. Although most objective assessments suggest that Iraqi forces will continue to need the assistance of U.S. forces to meet Iraq's internal and external threats after the end of 2011, domestic politics in Iraq and the United States suggest that security agreement will expire without renewal. This sort of assessment has led the administration of President Barack Obama to focus its efforts in Iraq on withdrawal of the current contingent of 48,000 U.S. troops by the end of the year. Accompanying this withdrawal is an intensified effort to transfer all the functions undertaken by the U.S. military to civilian entities. This transfer to civilian authority is complicated by the comparatively low capabilities of civilian agencies and the reluctance of the U.S. Congress to fund nonmilitary expenditures in Iraq. 
The departure of U.S. troops by the end of 2011 need not necessarily mean the curtailment of the U.S.-Iraq bilateral relationship. To many Iraqis and Americans, the logic of a strategic partnership-as laid out in the Strategic Framework Agreement-is self-evident. But developing such a relationship will require sustained commitment and hard work, given other draws on American resources, Iraq fatigue in the United States, and the panoply of issues about which Iraq and the United States could diverge in the years ahead.

The implications of the health of this bilateral relationship for Iraq's energy development are more fundamental than they may seem at first glance. Iraq is likely to struggle more with security challenges in the absence of U.S. support-particularly in intelligence, air power, border security, and high-end counterterrorism operations. But the real effects of a diminishing bilateral relationship-in the military and nonmilitary realms-are psychological and political. Although there is no question that Iraqis are tired of American involvement in their country, they also fear complete abandonment by the United States as many of them see America as the best antidote to their fears. Whether one is anxious about an Iranian takeover, the rise of unbridled power by Baghdad, or the resurgence of the Ba'ath Party, American commitment to Iraq is seen as a helpful bulwark. A true divergence between the United States and Iraq-while not inevitablewould likely have a detrimental effect on the political stability of the system overall.

Strangely, both energy and Iraq command their own space in American political discourse and in strategic discussions among experts and policymakers. When the two are connected, it is generally in the misleading context of debating whether the wars in Iraq were about American access to Iraqi oil. Rarely is there an appreciation of how closely the supply of energy and the price of energy are connected to stability in Iraq. This connection-which has to do not with American access to Iraqi oil specifically, but the ability of Iraq to bring more of its oil to global markets-should be front and center in the minds of American, Japanese, and international policymakers considering the variety of reasons why the world still needs to be concerned with Iraq's trajectory, and should keep support for Iraq's fledgling new institutions among its highest priorities. 


\section{About the Author}

Meghan L. O'Sullivan, D.Phil., is the Jeane Kirkpatrick Professor of the Practice of International Affairs at Harvard University's Kennedy School. Her expertise includes nation-building, counterinsurgency, the geopolitics of energy, decision-making in foreign policy, Iraq, Afghanistan, and Pakistan. Between 2004 and 2007, she was special assistant to President George W. Bush and Deputy National Security Advisor for Iraq and Afghanistan during the last two years of this tenure. She spent two years in Iraq, including a period in fall 2008 to help conclude the security agreement and strategic framework agreement between the United States and Iraq. Prior to this, O'Sullivan was senior director for strategic planning and Southwest Asia at the National Security Council; political adviser to the Coalition Provisional Authority administrator and deputy director for governance in Baghdad; chief adviser to the presidential envoy to the Northern Ireland peace process; and a fellow at the Brookings Institution. Her publications include Shrewd Sanctions: Statecraft and State Sponsors of Terrorism (2003). O'Sullivan is an adjunct senior fellow at the Council on Foreign Relations, a consultant to the National Intelligence Council, and a consultant to American oil and gas companies. She is also a foreign affairs columnist for Bloomberg View, a director on the board of TechnoServe, a nonprofit organization bringing business solutions to help alleviate poverty, and is on the advisory board of the George W. Bush Center Women's Initiative. She is also a member of the Council of Foreign Relations, the Trilateral Commission, and the Aspen Strategy Group. O'Sullivan has been awarded the Defense Department's highest honor for civilians, the Distinguished Public Service Medal, and three times been awarded the State Department's Superior Honor Award. She holds a doctorate in politics and a master's in economics from Oxford University and a B.A. from Georgetown University. 


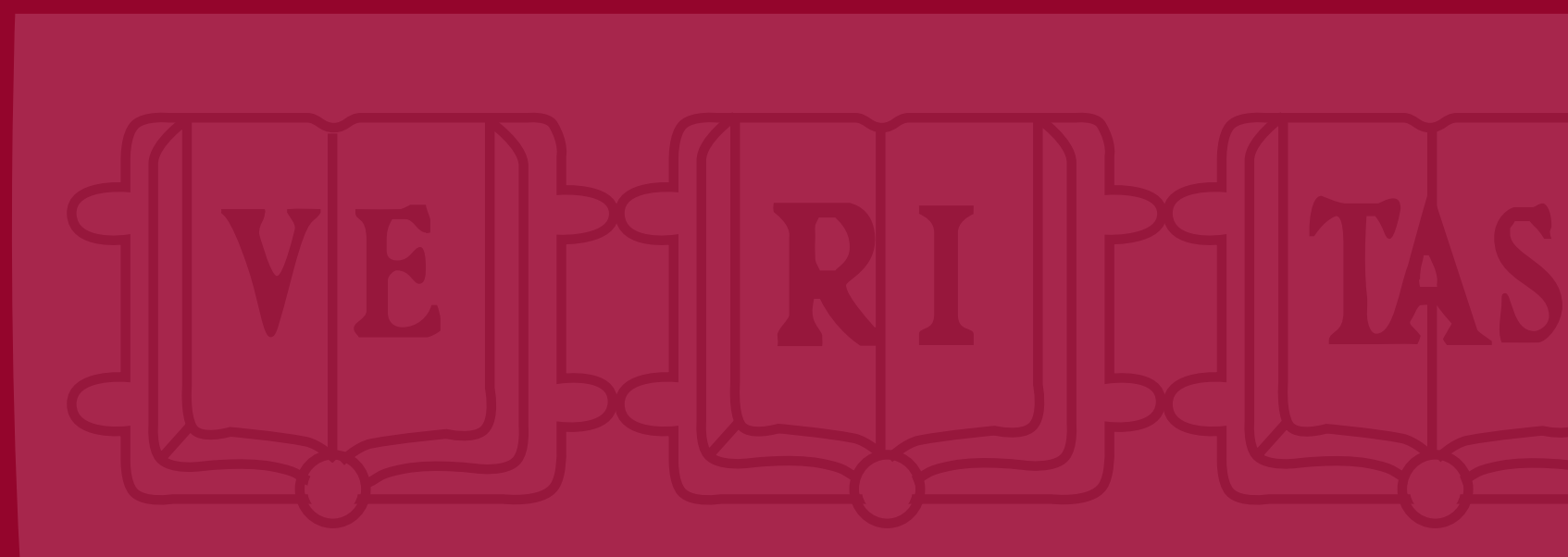

\section{Belfer Center for Science and International Affairs}

Harvard Kennedy School

79 JFK Street

Cambridge, MA 02138

Fax: (617) 495-8963

Email: belfer_center@harvard.edu

Website: http://belfercenter.org

Copyright 2011 President and Fellows of Harvard College 